\title{
Cyberbezpieczeństwo - praktyczne aspekty działań szkoły w programach eTwinning i Erasmus+
}

DOI: $10.47050 / 65591777.312-331$

Adam Stępiński, Jolanta Gradowska

Dla nauczycieli i uczniów biorących udział w projektach eTwinning i Erasmus+ zagadnienie cyberbezpieczeństwa ma znaczenie priorytetowe. Oprócz zadań, które są częścią ich pracy w projekcie, podejmują oni liczne inicjatywy w szkole i poza nią, propagujące odpowiedzialność młodego pokolenia w internecie. Przedsięwzięcia te mają formę konkursów, przedstawień, filmów, plakatów, które wskazują uczestnikom sprawdzone sposoby zachowań online oraz sposób postępowania w wypadku pojawienia się zagrożenia.

\section{Słowa kluczowe:}

cyberbezpieczeństwo

eTwinning

Erasmus+

projekty edukacyjne 


\section{Cybersafety - practical aspects \\ of school's activities in programs \\ e'Twinning and Hrasmus+}

DOI: 10.47050/65591777.312-331

Adam Stępiński, Jolanta Gradowska

For teachers and students participating in eTwinning and Erasmus+ projects, the issue of cyber security is a priority. In addition to the tasks that are part of their work within the project, they undertake numerous initiatives at school and beyond, which promote the responsibility of the young generation on the Internet. These activities take the form of contests, performances, films, posters that provide participants with proven online behaviour and how to proceed in the event of a threat.

\section{Keywords:}

cybersafety

eTwinning

Erasmus+

educational projects 


\section{Internet w życiu młodych ludzi}

Młodzi ludzie, dzieci i nastolatkowie, potrafią w pełni wykorzystywać szybki rozwój i potencjał internetu. Nie pamiętają czasów bez tego ważnego komponentu ich życia, a ich obecność online jest dla nich równie ważna, jak spotkanie się w rzeczywistości z przyjaciółmi czy wyjście do kina. We współczesnym świecie nie dziwi widok trzylatka sprawnie obsługującego tablet czy poszukującego bajek w serwisie YouTube. Internet stał się nieodłącznym elementem życia społecznego dzieci i młodzieży, towarzyszącym im przy codziennych zajęciach, i źródłem rozrywki.

Z rozmów z nastolatkami można się dowiedzieć, że codziennie korzystają z internetu, a online przebywają od kilku do kilkunastu godzin (Wrońska, Lange 2016). Młode pokolenia nie pytają, skąd wzięły się telefony komórkowe czy laptopy - urządzenia te są immamentną częścią ich życia.

Już na początku XXI w. Marc Prensky nazwał najmłodszych użytkowników internetu "cyfrowymi tubylcami", a ludzi starszych - "cyfrowymi imigrantami" (Prensky 2001, s. 1-6). Dla współczesnych nastolatków internet, w którego otoczeniu się wychowywali, jest najważniejszym medium. O ile kilka lub kilkanaście lat temu mówiło się, że dzieci urodziły się z myszką $w$ ręku, o tyle obecnie należałoby stwierdzić, że dorastają z kciukiem na klawiaturze smartfona.

Najpopularniejsze aktywności dzieci i młodzieży w internecie to oglądanie materiałów wideo i korzystanie z serwisów społecznościowych. Dalej plasują się takie czynności jak odrabianie prac domowych, poszukiwanie informacji czy pobieranie muzyki (Gursztyn 2014, s. 6). Zasoby sieci otwierają przed młodymi ludźmi ogromne możliwości, jednocześnie bardzo często wskazują oni wiele negatywnych elementów występujących w tym środowisku. Należą do nich między innymi cyberprzemoc, phishing (wyłudzanie danych osobistych i kradzież tożsamości w sieci), hejt, ujawnienie prywatnych wiadomości, nadużywanie i uzależnienie od internetu, nierozważne publikowanie fotografii, filmów i innych materiałów, promocja zachowań autodestrukcyjnych, łamanie praw autorskich, plagiatowanie, nadszarpnięta reputacja online, sexting czy niebezpieczne kontakty z nieznanymi użytkownikami.

Lista zagrożeń jest dużo dłuższa i nieustanie się zmienia wraz z rozwojem nowoczesnych technologii. Nadążenie za rozwojem sieci i wirtualnymi zainteresowaniami młodego pokolenia wydaje się zadaniem 
wręcz niewykonalnym. Dlatego potrzeba ustawicznego zwiększania wiedzy na ten temat zarówno wśród uczniów i ich rodziców, jak i nauczycieli. Ważne jest zrozumienie, że niekonieczne trzeba być ekspertem w zakresie nowych technologii, aby móc dyskutować z dziećmi o ich aktywnościach w internecie. Rodzice i nauczyciele powinni uczyć młode pokolenia odpowiedzialnego zachowania w cyberprzestrzeni oraz nieustannie uświadamiać dzieci i młodzież o internetowych zagrożeniach.

Tego rodzaju działaniom od ponad dwóch dekad towarzyszy Fundacja Rozwoju Systemu Edukacji, prowadząc szeroko zakrojone akcje dotyczące podnoszenia świadomości uczniów, ale również doskonaląc zawodowo nauczycieli, a pośrednio także oddziałując na rodziców.

\section{eTwinning jako społeczność świadomych użytkowników internetu}

Od początku istnienia eTwinning stawiał cyberbezpieczeństwo uczniów na czele swoich priorytetów. Współpraca w projektach eTwinning między przedszkolami i szkołami odbywa się w wirtualnej rzeczywistości. Biorąc pod uwagę powszechność programu w szkołach (ponad 630 tys. nauczycieli w Europie, ponad 200 tys. szkół, w tym prawie 60 tys. nauczycieli z Polski w ponad 16 tysiącach szkółł' ' zespoły projektowe eTwinning zwracają uwagę zarówno na bezpieczeństwo online uczestników projektów, jak i na upowszechnianie odpowiedzialnych zachowań, rozwój świadomości i wiedzy na ten temat w środowisku szkolnym i pozaszkolnym. "Uczniowie i nauczyciele wykorzystują internet we współpracy ponad granicami - współdziałają, wymieniają się informacjami i materiałami do nauki. eTwinning poszerza zakres pedagogicznych możliwości oferowanych uczniom i nauczycielom, motywuje do nauki i otwarcia na Europę" ${ }^{2}$. Uczestnicy projektu pracują wspólnie nad wcześniej zaplanowanymi działaniami, wykorzystując różnorodne narzędzia komunikacji synchronicznej i asynchronicznej.

W celu zapewnienia bezpieczeństwa nauczyciele rejestrujący się na portalu eTwinning są weryfikowani przez Krajowe Biuro eTwinning, co uniemożliwia rejestrację osobom niebędącym pedagogami. Nowi użytkownicy mają dostęp do platformy eTwinning Live, która umożliwia 
wyszukiwanie potencjalnych partnerów z innych krajów, udział w różnych formach doskonalenia zawodowego (na przykład webinariach i tzw. learning events - dwutygodniowych warsztatach online poświęconych tematyce związanej z pracą projektową). Na eTwinning Live istnieje także możliwość stworzenia własnego wydarzenia i zaproszenia na nie innych nauczycieli, realizacji współpracy i prowadzenia dyskusji na forach tematycznych, dołączenia do jednej z wielu grup nauczycieli oraz założenia projektu przedyskutowanego wcześniej z partnerami z innych krajów. Od kilku lat jest również możliwe prowadzenie projektu bez partnerów z zagranicy w ramach tzw. krajowego projektu eTwinning.

Po zaakceptowaniu złożonego zarysu projektu przez Krajowe Biuro eTwinning, nauczyciele uzyskują dostęp do platformy umożliwiającej współpracę - tak zwanych TwinSpace projektu. Również ta przestrzeń jest oddzielona od przypadkowych użytkowników internetu. Z tego poziomu nauczyciele tworzą konta dla swoich uczniów, podając im wygenerowane przez system loginy i hasła. Zapraszając uczniów do TwinSpace, należy otrzymać zgodę od rodzica bądź prawnego opiekuna dziecka. Ta sama zasada dotyczy publikowania zdjęć. Zalecane jest korzystanie z awatarów, ikonek lub figur reprezentujących daną osobę. Przed zaproszeniem uczniów zaleca się nauczycielom zapoznanie się z odpowiedziami na pięć pytań dotyczących e-bezpieczeństwa w eTwinningu i na TwinSpace, dostępnymi na europejskim portalu eTwinning ${ }^{3}$. Nowi użytkownicy eTwinning powinni zapoznać się także z normami postępowania (code of conduct), co ułatwi efektywną współpracę i wyeliminuje możliwe nieodpowiednie zachowania uczniów w projekcie ${ }^{4}$. Zgodnie z normami postępowania w eTwinningu należy zgłaszać wszelkie nieodpowiednie treści i e-maile noszące znamiona spamu. Komentarze muszą być kierowane do konkretnych osób i nawiązywać do określonego postu użytkownika. Należy również szybko reagować na bezpośrednie groźby, nawoływanie do przemocy ze względu na różnice w kolorze skóry, pochodzenie etniczne i narodowe, religię, orientację seksualną. Niestosowne treści graficzne są natychmiast usuwane. Zwraca się tam również uwagę na zagadnienie własno- 
ści intelektualnej oraz zasady zarządzające informacjami prywatnymi i danymi poufnymi.

Opracowano również trzy bardzo pomocne infografiki, które przejrzyście wyjaśniają, w jaki sposób należy chronić siebie online, dobierać swoje nowe kontakty w internecie i właściwie ocenić treść, którą chcemy opublikować 5 .

Z poziomu strony głównej można dokładać kolejne strony (zakładki) projektu, publikować materiały w trzech kategoriach (obrazy, filmy wideo, pliki), tworzyć nowe fora dyskusyjne, planować spotkania na czacie lub wideokonferencje oraz zarządzać uczestnikami projektu. Nauczyciele administratorzy mogą zmieniać role użytkownikom (uczeń - uczeń administrator), zapraszać do projektu nowe osoby, resetować hasła dostępu uczniów, eksportować listy członków oraz ich usuwać. Istnieje możliwość skontaktowania się z wieloma uczestnikami jednocześnie i pojedynczo. Niezwykle ciekawym ustawieniem jest rola "gościa", który może jedynie przyglądać się postępującej pracy, ale nie może niczego od siebie dodawać. Warto w tym charakterze zaprosić dyrektora szkoły, gdyż może on wtedy na przykład sprawdzić, czy w projekcie są przestrzegane zasady bezpieczeństwa pracy online.

W sekcji "Tendencje/kwestie/polityki i praktyki” na stronie europejskiego eTwinningu przedyskutowano w formie pytań i odpowiedzi zagadnienia dotyczące: praw i obowiązków uzytkowników, prywatności i ochrony danych oraz praw autorskich ${ }^{6}$. Strona ta zawiera również link do Kodeksu unijnych praw internetowych. Jest to niezwykle interesujący dokument, który może posłużyć jako materiał źródłowy do dyskusji klasowych czy opracowania zadań projektowych w tematyce e-bezpieczeństwa. Inne niezwykle ważne zagadnienia poruszane w formie pytań i odpowiedzi to:

$\rightarrow$ sieci i media społecznościowe;

$\rightarrow$ problemy związane z komunikacją internetową poza eTwinningiem;

$\rightarrow$ Dzień Bezpiecznego Internetu? 


\section{Projekty eTwinning a cyberbezpieczeństwo}

Program eTwinning stawia minimum wymagań. Chętnym do stworzenia projektu wystarczy komputer $z$ dostępem do internetu. Oferowane narzędzia są łatwe w obsłudze i bezpieczne dla uczniów, którzy mają możliwość skorzystania z nich bez obaw o ingerencję z zewnątrz i dostęp do nieodpowiednich treści. Każdy nauczyciel może równolegle z kolegami z tej samej szkoły prowadzić nawet kilka projektów - zależy to wyłącznie od jego chęci, czasu i możliwości.

Rozpoczynając realizację projektu, nauczyciele zapoznają uczniów z zasadami bezpiecznej pracy online. Odbywa się to w szkołach przez zorganizowanie specjalnych zajęć, podczas których wszyscy uczestnicy dzielą się swoją wiedzą na temat reguł bezpiecznego korzystania z internetu. Często ta właśnie tematyka zawarta jest w konkretnych zadaniach projektowych wykonywanych wspólnie z partnerami. Uczniowie tworzą na przykład plakaty, słowniczki pojęć z zakresu e-bezpieczeństwa, komiksy, filmiki, animacje, prezentacje przedstawiające najważniejsze wskazówki na polu bezpiecznej pracy online. Korzyści z takiego zorganizowania zadania to, oprócz praktycznego przyswojenia sobie zasad bezpieczeństwa, również dobra zabawa, która wpływa na wzrost motywacji do pracy w projekcie.

Bardzo częstą praktyką stosowaną w projektach eTwinning jest przygotowanie na początku pracy zasad netykiety, czyli sposobu odnoszenia się do siebie, komentowania prac kolegów, umieszczania materiałów, zdjęć i filmów. Wszyscy uczniowie głosują za poszczególnymi propozycjami i w ten sposób powstaje wspólnie wypracowany kanon zachowań i postaw w pracy projektowej. Dzięki temu, oprócz wpływania na sferę postaw uczniów, propagowana jest zasada zachowań demokratycznych, dyskusji i wspólnego wyboru propozycji zaakceptowanych przez wszystkich uczestników.

Uczniowie i nauczyciele zaangażowani w projekty eTwinning są również często w swoich placówkach i środowiskach inicjatorami szerszych akcji upowszechniających cyberbezpieczeństwo. Przygotowując wystawy plastyczne na korytarzach szkolnych, opracowując scenariusze przedstawień i filmów o uczniowskich zachowaniach w internecie, a następnie je wystawiając, są oni $z$ jednej strony propagatorami pożądanych zachowań w internecie, z drugiej zaś przestrzegają swoich kolegów przed lekkomyślnością, pokazując konsekwencje nieodpowiedzialnych poczynań. 


\section{Przykłady projektów eTwinning o tematyce cyberbezpieczeństwa}

Projekty eTwinning na temat bezpieczeństwa w sieci są często wynikiem obserwacji nauczycieli, którzy dostrzegają realne problemy, przed jakimi stają ich uczniowie. Tak również było w wypadku projektu "Being aware, feeling e-safe" ${ }^{8}$ realizowanego przez Szkołę Podstawową im. ks. mjr. Franciszka Łuszczki w Lubeni i Liceul de Arte "Ionel Perlea" z Rumunii.

Na początku uczniowie pisali do siebie, poznając się wzajemnie. Do przedstawiania się używali między innymi aplikacji Voki. Każdy uczeń miał swojego awatara i nie było konieczności publikowania zdjęć. W trakcie realizacji projektu uczestnicy stworzyli wspólnie kodeks netykiety, którego zobowiązali się przestrzegać w trakcie pracy, przygotowali hasła na temat e-bezpieczeństwa, których celem było propagowanie bezpiecznych zachowań w sieci, zorganizowali i przeprowadzili konkurs na plakat lansujący bezpieczny internet, opracowali materiały do tematycznych krzyżówek i quizów wykonanych w aplikacji LearningApps. W trakcie prac uczestnicy wykorzystywali między innymi aplikację Tricider do przygotowania haseł upowszechniających e-bezpieczeństwo oraz dokumenty dysku Google Drive do opracowania formularzy ankiet.

Głównym celem projektu było propagowanie zasad korzystania z zasobów online. Uczniowie rozwinęli swoje umiejętności cyfrowe i informatyczne, a przez współpracę z partnerami z zagranicy znacznie poszerzyli również kompetencje społeczne i obywatelskie, umiejętność pracy w zespole oraz komunikowania się w języku obcym. Nauczyli się także tworzyć swój profil w mediach społecznościowych, dowiedzieli się, jak chronić pocztę przed próbami wyłudzenia informacji i jak postępować w wypadku doświadczenia agresji w internecie.

Ponieważ projekt miał charakter interdyscyplinarny, materiały dydaktyczne wypracowane w czasie jego trwania mogą być wykorzystywane w ramach różnych przedmiotów. Są one dostosowane do prowadzenia zajęć z wykorzystaniem nowoczesnych technologii, a z drugiej strony mogą być polecane uczniom do samodzielnej pracy w domu.

W ramach projektu zorganizowano w szkołach Dzień Bezpiecznego Internetu oraz przygotowano szkolną gazetkę ścienną prezentującą 
tematyczne plakaty. Poza tym przeprowadzono quiz dla uczniów klas IV i V, sprawdzający praktyczną wiedzę o internecie i bezpiecznym korzystaniu z mediów elektronicznych. „Being aware, feeling e-safe" został zaprezentowany podczas webinaru prowadzonego w ramach grupy Bringing e-safety into eTwinning Projects. Projekt został wyróżniony Krajową i Europejską Odznaką Jakości, a w 2017 r. został laureatem konkursu "Nasz projekt eTwinning 2017".

Innym przykładem projektu propagującego cyberbezpieczeństwo jest "Digital citizenship: Better eSafe than Sorry" ${ }^{9}$, prowadzony przez IES San José w Hiszpanii, Michael College z Holandii, Hristo Smirnenski Primary School w Bułgarii, Herskind Skole \& Børnehus w Danii i Collège Paul Gauguin we Francji. Motywem przewodnim tego przedsięwzięcia była chęć odpowiedzi na pytanie o to, czy wiemy, jak bezpiecznie i odpowiedzialnie korzystać z internetu. Oprócz tego do głównych celów projektu należały: rozpropagowanie wykorzystania nowych technologii w tematyce cyfrowego bezpieczeństwa, doskonalenie umiejętności językowych uczestników, poprawa efektywności pracy grupowej, zapoznanie się z różnicami kulturowymi i poszanowanie ich oraz pozyskanie wskazówek, jak zachować się w wypadku nękania w internecie oraz manipulowaniem informacjami. Zwieńczeniem projektu było stworzenie dokumentów szkolnych regulujących sferę korzystania i dostępu do nowych technologii w szkole.

W ramach projektu zapraszano do szkół ekspertów, którzy dzieli się z uczniami wiedzą i proponowali im pewne działania. Szczególną uwagę zwrócono na niekontrolowane używanie przez uczniów urządzeń mobilnych. Zadania projektowe skupiały się na kwestiach odpowiedzialnego korzystania z internetu, propagowania właściwych norm zachowania na portalach społecznościowych oraz szeroko pojętych prawach i obowiązkach młodych użytkowników.

Do realizacji przedsięwzięcia wykorzystano metodologię nauczania opartego na pracy projektowej i współpracy między uczniami. Nauczyciele podzielili swoich podopiecznych na międzynarodowe grupy zadaniowe. Uczestnicy projektu prowadzili wśród swoich kolegów i koleżanek badania dotyczące bezpieczeństwa online oraz korzystania z nowoczesnych urządzeń. Każdy zespół zajmował się innym tematem. 
Po zakończeniu zbierania informacji uczestnicy mieli za zadanie zaprezentować innym zespołom wnioski ze swojej pracy. Dzięki wykorzystaniu zasobów na portalu webwewant.eu uczniowie mogli pracować nad następującymi tematami: prawa i obowiązki użytkowników internetu, netykieta, portale społecznościowe, prywatność i prawa autorskie. Brali oni również udział w Dniu Bezpiecznego Internetu 2016. Z kolei dzięki wsparciu Chaval Spain uzyskali dostęp do serii zabawnych ćwiczeń z wykorzystaniem aplikacji SmartPRIVAL.

Uczestnicy opracowali wiele kwestionariuszy online, które były dostępne w projektowej części TwinSpace. Grupa hiszpańska brała udział w inicjatywie tamtejszego resortu edukacji zatytułowanej Digital Natives Forum. Jej głównym celem było podniesienie świadomości w zakresie odpowiedzialnego wykorzystania narzędzi informatycznych. W ramach prac wyłoniona została grupa uczniów, nazwanych tutorami, którzy przekazywali wiedzę i umiejętności na temat cyberbezpieczeństwa swoim rówieśnikom.

Tymczasem nauczyciele opracowali obszerny dokument - Digital Action Plan - zbierający najważniejsze zagadnienia w zakresie e-bezpieczeństwa w szkole. Pierwszym etapem było przeprowadzenie analizy potrzeb w obszarze tematycznym projektu. Następnie przygotowano konkretne rozwiązania, które były odpowiedzią na zaobserwowane problemy i wskazówkami, jak się zachować w różnych sytuacjach. Do opracowania Digital Action Plan wykorzystano materiały dostępne na portalu esafetylabel.eu. Opracowane sugestie są zawarte w dwóch dokumentach, które każda szkoła może dodać swojego corocznego planu pracy: „Zasady akceptowalnego wykorzystania internetu przez personel szkolny" i "Zasady akceptowalnego wykorzystania internetu przez uczniów".

Niezwykle interesującą częścią projektu jest porównanie kilku krajów, które pokazuje różnice w podejściu do internetu widoczne między młodymi Europejczykami. Dzięki ankietom na Google Docs opracowano wiele pouczających zestawień. Nastolatkowie w różnych krajach wykorzystują telefony do tych samych celów i spędzają porównywalną ilość czasu w sieci. Najbardziej popularnymi portalami społecznościowymi są Facebook i Twitter, chociaż wśród Hiszpanów WhatsApp wykorzystywany jest równie chętnie. Wszyscy uczestnicy projektu zetknęli się bezpośrednio lub pośrednio z problemem cybernękania, a dzięki temu 
przedsięwzięciu dowiedzieli się, jak reagować w trudnych sytuacjach, jak rozwiązywać problemy i do kogo zwrócić się o pomoc.

W ramach projektu zorganizowano prelekcje o cyberbezpieczeństwie dla uczniów i rodziców, które były prowadzone przez policjantów i ekspertów z zakresu nowoczesnych technologii. W prace nad rozpowszechnianiem rezultatów zaangażowało się stowarzyszenie rodziców, którego wysiłki ujawniły, że poziom wiedzy starszych pokoleń o nowych technologiach i zagrożeniach, jakie się z nimi wiążą, jest bardzo zróżnicowany. O ile większość rodziców zdawała sobie sprawę ze skali skali zjawiska nękania młodych ludzi w internecie, o tyle niewielka część wiedziała, jakie instytucje mogą im pomóc w sytuacjach kryzysowych. Wysiłki w ramach projektu "Better eSafe than Sorry" zostały nagrodzone srebrną odznaką e-Safety Label.

Kolejnym przykładem przedsięwzięcia eTwinning, które w centrum uwagi uczestników stawiało e-bezpieczeństwo, był projekt "Take care of me - take care of you", który w 2018 r. zajął drugie miejsce w konkursie europejskim na przedsięwzięcia kierowane do dzieci w wieku 4-11 lat. W roku szkolnym 2017/2018 brało w nim udział 107 uczniów z pięciu państw (Polska, Portugalia, Francja, Ukraina i Włochy). Najważniejsze tematy poruszane $w$ trakcie tej inicjatywy dotyczyły: nękania w internecie, przyczyn zachowań agresywnych online wśród młodych ludzi, propagowania odpowiedzialnych postaw podczas aktywności online. Oprócz tradycyjnych sposobów przedstawienia się na początku projektu (forum, zdjęcia, filmy) uczestnicy tworzyli także dla swoich kolegów i koleżanek quizy, wykorzystując do tego celu aplikację LearningApps ${ }^{10}$.

Innym zadaniem było przygotowanie logotypu projektu w ramach pracy w międzynarodowych zespołach. Korzystając z aplikacji Padlet, uczniowie pracowali nad definicją nękania online, współdziałając zaś z twórcami komiksów, przygotowali historyjki tematyczne. Nagrywanie filmów wideo o tematyce cyberbezpieczeństwa przyniosło uczniom wiele satysfakcji i dodatkowo zmotywowało ich do dalszej pracy. 


\section{Dzień Bezpiecznego Internetu}

Co roku uczestnicy projektów eTwinner biorą udział w lutowym Dniu Bezpiecznego Internetu. W jego trakcie są propagowane działania na rzecz bezpiecznego dostępu dzieci i młodzieży do zasobów internetowych, z kolei rodzice, nauczyciele i wychowawcy szerzej zaznajamiają się ze sposobami pozytywnego wykorzystania zasobów online. Ideą Dnia Bezpiecznego Internetu, podobnie jak przedsięwzięć eTwinning, jest podkreślenie siły współdziałania w sprawie cyfrowego bezpieczeństwa na poziomie zarówno międzynarodowym, jak i lokalnym. W ramach tego wydarzenia są organizowane tematyczne zajęcia edukacyjne, pogadanki, happeningi, kampanie informacyjne, konkursy, a niektóre szkoły wydają okolicznościowe gazetki. Inicjatywy mogą być zgłaszane do ogólnopolskiego konkursu na najciekawsze obchody Dnia Bezpiecznego Internetu'11.

Wiele szkół skupionych w sieci placówek eTwinning korzysta z otrzymanych materiałów edukacyjnych i promocyjnych, pomocnych w przygotowaniu obchodów. Organizatorzy zapewniają także dostęp do narzędzi edukacyjnych online - materiałów multimedialnych, kursów e-learningowych, scenariuszy zajęć oraz poradników i broszur.

W 2018 r. Dzień Bezpiecznego Internetu zorganizowano pod hasłem „Tworzymy kulturę szacunku w sieci". Wielu nauczycieli zaangażowanych w eTwinning wzięło udział w kursie MOOC "Bezpieczeństwo w sieci". Jego celem było wyposażenie uczestników w niezbędną wiedzę i przydatne narzędzia, które umożliwią im przeciwdziałanie niegodziwemu traktowaniu w środowisku online, mowie nienawiści i radykalizacji, cybernękaniu czy szantażowi za pomocą intymnych zdjęć ${ }^{12}$.

\section{Odznaka eSafety Label}

Nauczyciele prowadzący projekty eTwinning mogą się ubiegać o uzyskanie odznaki eSafety Label. Jest ona przyznawana w ramach ogólnoeuropejskiej inicjatywy, której celem jest zapewnienie bezpiecznego dostępu do technologii online jako części procesu nauczania i uczenia się. Strona internetowa eSafety Label pomaga nauczycielom, dyrektorom i administratorom sieci ocenić bezpieczeństwo ich szkół w internecie, 
opracować i wdrożyć plan działania oraz - w fazie końcowej-podzielić się przykładami dobrych praktyk z innymi szkołami.

Projekt eSafety Label zainicjowano w Dniu Bezpiecznego Internetu w 2012 r. Od początku wielu uczestników projektów eTwinning z różnych krajów europejskich zaangażowało się aktywnie w prace zespołu, który przyczynił się do wypracowania formularza oceny - niezbędnego do przeprowadzenia ewaluacji poziomu bezpieczeństwa szkoły online oraz wskazania obszarów wymagających poprawy i dalszej pracy ${ }^{13}$.

Żeby otrzymać odznakę eSafety Label, należy zapoznać się z zasobami portalu i zarejestrować placówkę, co jest jednocześnie początkiem całego procesu akredytacyjnego. Następnie, we współpracy z innymi szkołami, prowadzi się analizę stanu wyjściowego, na podstawie którego możliwe jest nakreślenie planu rozwoju i wdrażania konkretnych rozwiązań.

Odznaka jest przydzielana na 18 miesięcy, a po upływie roku rozpoczyna się nowy proces akredytacyjny. Dzięki temu możliwe jest ciągłe ulepszanie cyberbezpieczeństwa szkoły. Istnieją cztery poziomy odznaki: żelazna (poziom podstawowy e-bezpieczeństwa), brązowa (poziom średni), srebra (poziom bardziej zaawansowany) oraz złota (wyróżniające się praktyki w obszarze cyberbezpieczeństwa w szkole) ${ }^{14}$.

Od niedawna w ramach eSafety Label jest możliwe przystąpienie do projektu eSafety Champions. Trwa on 28 miesięcy i stawia sobie za cel wymianę wiedzy i dobrych praktyk wśród nauczycieli i szkół, które chcą rozwijać u swoich uczniów nawyki odpowiedzialnego wykorzystania nowoczesnych technologii. Uczestnicy eSafety Champions biorą udział w serii szkoleń online, webinariów oraz w trzydniowym kursie w Future Classroom Lab w Brukseli. Opracują także materiały do kursu MOOC, przeznaczonego dla tysięcy nauczycieli w Europie ${ }^{15}$.

\section{Rozpropagowanie szkół eTwinning dbających o e-bezpieczeństwo}

W ramach programu eTwinning docenia się realizatorów projektów zarówno nauczycieli, jak i placówki - co sprzyja promocji e-bezpieczeń- 
stwa. Od 2018 r. zainteresowane podmioty mogą się ubiegać o Odznakę Szkoła eTwinning.

Jednym z obowiązkowych kryteriów, które muszą być spełnione, żeby placówka mogła zostać nagrodzona Odznaką Szkoły eTwinning, jest prezentacja zrealizowanych przez nią działań związanych ze znajomością zasad poprawnego korzystania z sieci. Weryfikacja opiera się bezpośrednio na zagadnieniach zawartych w formularzu oceny, związanym z procedurą przyznawania odznaki eSafety Label, i wymaga od przedstawicieli szkoły udzielenia odpowiedzi na serię pytań, które łatwo pozwalają ocenić, czy dana placówka ma odpowiednią wiedzę na temat e-bezpieczeństwa oraz przeprowadza celowe i systematyczne działania w tym zakresie. Pytania zawarte w formularzu aplikacyjnym odnoszą się do trzech obszarów:

$\rightarrow$ infrastruktura (ochrona danych osobowych, zarzadzanie sprzętem z zakresu technologii informacyjno-komunikacyjnych, zabezpieczenie sieci szkolnej);

$\rightarrow$ polityka e-bezpieczeństwa (znajomość praw autorskich, obecność w mediach społecznościowych, standardy bezpieczeństwa online);

$\rightarrow$ dobre praktyki (programy nauczania uwzględniające tematykę e-bezpieczeństwa, spotkania informacyjne dla rodziców, konsultacje).

Zgodnie z wytycznymi szkoła ubiegająca się o odznakę prezentuje konkretne aktywności potwierdzające świadome, bezpieczne i odpowiedzialne korzystanie z zasobów internetu zarówno przez uczniów, jak i przez nauczycieli - nie tylko w ramach realizacji projektów eTwinning, ale także w codziennej aktywności w szkole i poza nią.

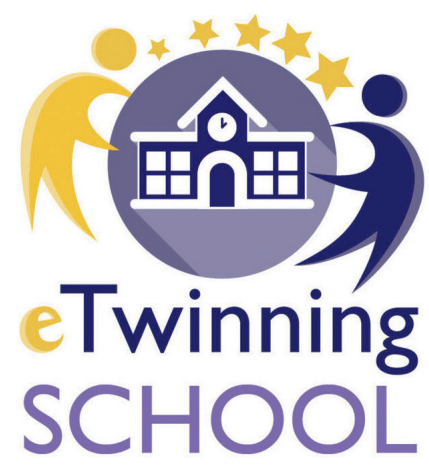

Odznaka Szkoła eTwinning to narzędzie, które wpływa na utrzymanie wysokich standardów w obszarze e- bezpieczeństwa w programie eTwinning, a szkołom, nauczycielom i uczniom w nim uczestniczącym umożliwia dalszy rozwój, wskazując elementy wymagające poprawy i zapewniając wsparcie merytoryczne w tym zakresie. 


\section{Publikacje eTwinning}

W publikacjach eTwinning dużo uwagi poświęca się zagadnieniom cyberbezpieczeństwa. Przykładem jest broszura z 2016 r. Rozwijanie świadomości cyfrowej obywatela. Aktywny rozwój postawy obywatelskiej poprzez eTwinning, zawierająca opis trzech projektów poświęconych bezpieczeństwu w internecie: „Better e-Safe than Sorry”, "Medienkoffer" $i$ "Net is the Key". Pomysły tam zaprezentowane mogą być inspiracją dla nauczycieli chcących zająć się tą tematyką ${ }^{16}$.

Poradnik Człowiek, komputer i Internet. W cyfrowym świecie to kompendium wiedzy dla osób początkujących, które rozpoczynają przygodę z komputerem. Z tej publikacji dowiedzą się one, jak efektywnie szukać potrzebnych zasobów w internecie, jak publikować w sieci, jakie możliwości nauki i samorozwoju oferują kursy online, na co należy zwrócić uwagę przy zakupach czy w jaki sposób się zachowywać, aby być bezpiecznym w sieci ${ }^{17}$. Poradnik cieszy się wśród nowych uczestników projektów eTwinning bardzo dużym zainteresowaniem, gdyż poziom znajomości nowoczesnych technologii w środowisku nauczycielskim nie jest jeszcze wysoki.

Inna publikacja eTwinning - Korzystanie z telefonu komórkowego w szkole. Zarzq̨dzanie szansami i zagrożeniami - przedstawia wiele aspektów związanych z upowszechnieniem telefonów komórkowych u dzieci i młodzieży. Poruszane są w niej następujące zagadnienia: rola telefonów w codziennym życiu młodego człowieka, zjawisko przemocy i pornografii, możliwości uczenia się oraz nauczania z wykorzystaniem tych urządzeń. Na szczególną uwagę zasługuje ostatni rozdział książki, w którym zaprezentowano praktyczne ćwiczenia dla różnych grup wiekowych w kreatywnym wykorzystaniu telefonów komórkowych ${ }^{18}$. Po zapoznaniu się z tym przewodnikiem można wyrobić sobie obiektywną opinię i samemu zdecydować, czy warto wykorzystywać komórki w procesie lekcyjnym i podczas pracy projektowej.

Na oddzielną uwagę zasługuje publikacja The Web We Want ${ }^{19}$, która była rozwijana w ostatnich kilku latach przez uczniów, nauczycieli 
i specjalistów z zakresu e-bezpieczeństwa pod patronatem European SchoolNet. Bardzo duży wkład w powstanie tej publikacji mieli nauczyciele - uczestnicy projektów eTwinning - i ich uczniowie.

Nastolatkowie z kilkunastu krajów europejskich opracowali podręcznik dla swoich kolegów, a nauczyciele i specjaliści - przewodnik metodyczny zawierający scenariusze zajęć i pomysły na ciekawe zadania, które można przeprowadzić z uczniami zarówno podczas lekcji, jak i w trakcie projektu edukacyjnego. Kolejne rozdziały podręcznika i przewodnika metodycznego są poświęcone następującym zagadnieniom: prawa i obowiązki w internecie, charakter informacji online, aktywność dzieci i młodzieży w wirtualnym świecie, tożsamość online, znaczenie i ochrona prywatności. W scenariuszach lekcji zaproponowano konkretne zadania i pomysły, których celem jest zachęcenie młodych ludzi do rozwijania kreatywnego i krytycznego myślenia, aby mogli oni czuć się w pełni spełnieni w świecie przyszłości oraz nabyć umiejętności potrzebne w przyszłych zawodach. Wszystkie wymienione materiały wpisują się w europejski zarys kompetencji kluczowych20, który jest wskaźnikiem dróg poszerzania wiedzy i umiejętności w państwach członkowskich Unii Europejskiej.

Prowadzenie portalu The Web We Want w kilkunastu językach daje szanse wykorzystania tych materiałów w przedsięwzięciach międzynarodowych online (na przykład eTwinning), podczas lekcji w szkołach i w projektach uwzględniających wizyty uczniów w placówkach partnerskich (na przykład Erasmus+).

\section{Grupa eTwinning "Bringing eSafety into eTwinning projects"}

Wymianie doświadczeń i dobrych praktyk między nauczycielami uczestniczącymi w projektach eTwinning służy kilkanaście grup specjalistycznych (eTwinning Groups), których zadaniem jest poszerzanie wiedzy i umiejętności ich członków. Jedną z nich jest „Bringing eSafety into eTwinning projects" (Wprowadzanie e-bezpieczeństwa do projektów eTwinning), licząca ponad 3,3 tysiąca członków.

Głównym celem tej grupy jest:

$\rightarrow$ zapewnienie nauczycielom wsparcia w obszarze bezpiecznego korzystania przez uczniów z mediów elektronicznych i z zaso- 
bów online (szczególnie w wymiarze prowadzonych projektów eTwinning);

$\rightarrow$ rozwój umiejętności przygotowywania własnych materiałów dydaktycznych do promocji e-bezpieczeństwa;

$\rightarrow$ dzielenie się wiedzą, dobrymi praktykami i sprawdzonymi zadaniami między nauczycielami z Europy.

Poza forum, na którym są omawiane bieżące zagadnienia i tematyka prac, grupa opracowała: szczegółowe zasady netykiety w projekcie eTwinning, przewodnik bezpiecznego korzystania z TwinSpace, wskazówki poświęcone prawu autorskiemu, a także bank zasobów i materiałów do wykorzystania w projektach oraz w codziennej pracy szkolnej. W ramach grupy zorganizowano pięć tematycznych webinariów, podczas których zaproszeni specjaliści zaprezentowali sieć edukatorów propagujących świadomość online młodzieży, przedstawili publikację The Web We Want czy omówili zagadnienie tożsamości online. Członkowie grupy przeprowadzili z własnej inicjatywy wiele spotkań na żywo (live events), podczas których zaprezentowali przykłady dobrych praktyk i projekty poświęcone tematyce cyberbezpieczeństwa.

\section{Kurs online "Tydzień z e-safety"}

Od kilku lat polscy nauczyciele otrzymują wsparcie w rozwoju wiedzy i umiejętności związanych z bezpiecznym korzystaniem z mediów elektronicznych, uczestnicząc w kursie online "Tydzień z e-safety". Jest on prowadzony na platformie Moodle, która daje możliwości udziału w dyskusjach na forach tematycznych, wyrażenia opinii w głosowaniu, tworzenia słownika poświęconego terminom związanym z cyberbezpieczeństwem, dzielenia się pomysłami na konkretne zadania, lekcje i projekty w obszarze e-safety, udział w sesjach "na żywo" (czaty i wideokonferencje) czy zaznajomienia się z materiałami tekstowymi oraz audiowizualnymi ${ }^{21}$.

Kurs jest siedmiodniowy i ma charakter zadaniowy. Podzielony jest na kilka modułów. Pierwszy z nich poświęcono zagrożeniom w internecie. Poruszane są w nim tematy cyberprzemocy i cyberprzestępstw, niebezpiecznych kontaktów i treści, sextingu oraz bezpieczeństwa 
uczniów online. Inny moduł dotyczy nadużywania internetu i uzależnienia od mediów elektronicznych. Kolejne części koncentrują się na ochronie prywatności i danych, własności intelektualnej, portalach społecznościowych, zabezpieczeniach komputera, rodzajach złośliwego oprogramowania, kontroli rodzicielskiej na urządzeniu mobilnym i plikach cookies. Osobną część stanowią ćwiczenia przygotowane na platformie LearningApps. Mogą być one wykorzystywane jako praca domowa, zadania do samodzielnego wykonania na komputerze w szkole bądź na tablicy multimedialnej wraz z całą grupą uczniowską. Ta ostatnia forma pracy przyczynia się szczególnie do wzrostu motywacji i zainteresowania uczniów.

Biorąc udział w kursie, nauczyciele poświęcają godzinę lub dwie godziny dziennie na zapoznanie się z materiałami i wykonanie zadań. Uczestnicy mają całodobowy dostęp do platformy Moodle, materiałów szkoleniowych i treści zadań. W razie potrzeby korzystają ze wsparcia trenera na forum pomocy. Często także zainteresowane osoby doprecyzowują między sobą szczegóły nowych projektów eTwinning (zarówno polskich, jak i międzynarodowych), w których e-bezpieczeństwo jest częścią poruszanej problematyki.

\section{Cyberbezpieczeństwo w projektach Erasmus+}

Podobnie jak w wypadku eTwinning, wiele projektów Erasmus+ w ramach Akcji 2. „Partnerstwa strategiczne na rzecz edukacji szkolnej” częściowo lub w całości poświęcono tematyce cyberbezpieczeństwa. W ich ramach uczniowie mają możliwość nie tylko współpracy online, ale także spotkania się i współdziałania w świecie rzeczywistym.

W latach 2014-2016 uczniowie z grójeckiego Liceum im. Piotra Skargi wraz z partnerami z Grecji, Norwegii, ze Szwecji i z Austrii pracowali nad projektem „Safe Internet for all". Dotyczył on zagrożeń związanych z korzystaniem z internetu i propagował bezpieczne sposoby pracy w wirtualnej rzeczywistości, zgodne z netykietą i zasadami etyki. Zakres tematyczny projektu obejmował następujące zagadnienia: uzależnienia od internetu, zagrożenia spowodowane nadmiernym korzystaniem z komputera, zabezpieczenia przed wirusami i spamem, netykieta i etyka w sieci. Każdy temat był opracowany przez jednego partnera z projektu, co doprowadziło do stworzenia kilku przewodników dla młodych ludzi korzystających z internetu. Nad tematami pracowano we współpracy z ekspertami, wykładowcami akademickimi i organiza- 
cjami pozarządowymi. Licealiści z Grójca zaprosili do siebie eksperta z Centrum Rozwoju Osobistego Alter, który przybliżył im zagadnienia cyberbullyingu i cyberstalkingu. $\mathrm{W}$ trakcie pięciu wymian międzynarodowych uczniowie omawiali kolejne moduły tematyczne, a po powrocie $z$ wyjazdu przybliżali te zagadnienia kolegom ze szkoły w trakcie warsztatów. Oprócz przewodników opracowano także broszurę Jak się uzależnić w 7 dni?, aplikację na Androida, filmy i prezentacje22.

Inny projekt Erasmus+ o podobnej tematyce - "Kamuflaż i bezpieczeństwo w świecie wirtualnym" - był prowadzony w latach 2015-2017 przez Zespół Szkół w Pobiedziskach z partnerami z Bułgarii, Grecji, Cypru i Portugalii. Głównym celem projektu było podniesienie świadomości na temat e-bezpieczeństwa wśród uczniów, nauczycieli, rodziców, osób odpowiedzialnych za politykę oświatową na szczeblu lokalnym i ogólnokrajowym, a także w społecznościach lokalnych. Ponieważ cyberbezpieczeństwo jest kluczowym zagadnieniem w szkołach ery cyfrowej, koordynatorzy projektu postawili sobie zadanie przekazania uczniom kompetencji, które ułatwią im pracę i codzienne życie w przyszłości.

Powstał przewodnik, który może być wykorzystany przez każdą szkołę podstawową w Europie. Partnerzy projektu wymieniali się także przykładami dobrych praktyk. Uniwersytet w Coimbrze (partner projektu z Portugalii), który ma bogate doświadczenie w międzynarodowych badaniach i projektach w tematyce cyberprzemocy, prowadził szkolenia dla nauczycieli. W trakcie dwuletniej pracy projektowej odbyły się trzy spotkania typu kickoff meeting - inicjujące współpracę w Portugalii, dotyczące mobilności na Cyprze i podsumowujące w Grecji23.

Umożliwiając szkołom udział w Akcji 1. Mobilność kadry edukacji szkolnej Erasmus+ wspiera nauczycieli w podnoszeniu kompetencji zawodowych. Uczestnicząc w zagranicznych kursach i szkoleniach dotyczących cyberbezpieczeństwa kadra szkolna zapoznaje się z nowoczesnymi metodami edukacyjnymi, które przyczyniają się do propagowania odpowiedzialnego korzystania przez młode pokolenie z zasobów internetu. Erasmus+, prowadząc bazę dostępnych kursów ${ }^{24}$, pomaga 
szkołom znaleźć szkolenia najbardziej pasujące do ich potrzeb w tematyce e-bezpieczeństwa oraz przypomina o ogólnoeuropejskich przedsięwzięciach upowszechniających bezpieczne korzystanie z zasobów online, takich jak Dzień Bezpiecznego Internetu25.

W maju 2018 r. Narodowa Agencja Programu Erasmus+ zorganizowała w Zakopanem konferencję pod hasłem „Szkoła w świecie zmian i nowych technologii". Uczestnicy jednego z warsztatów - "Cyberbezpieczeństwo w szkołach: skuteczne strategie działania" - mogli się zapoznać $z$ różnymi typami działań, które przyczyniają się do lepszego funkcjonowania młodego pokolenia w sieci, dowiedzieć się, jak włączyć strategię e-bezpieczeństwa w praktykę szkolną, oraz zaznajomić się z efektywnymi sposobami motywowania dzieci i młodzieży do odpowiedzialnego korzystania z mediów elektronicznych.

Podsumowując, warto stwierdzić, że dla nauczycieli i uczniów biorących udział w projektach eTwinning i Erasmus+ zagadnienie cyberbezpieczeństwa ma znaczenie priorytetowe. Oprócz zadań będących częścią ich pracy w projekcie podejmują oni liczne inicjatywy w szkole i poza nią, które propagują odpowiedzialność młodego pokolenia w internecie. 